\title{
Faith communities, social exclusion, homelessness and disability: Transforming the margins in the City of Tshwane
}

Authors:

Thinandavha D. Mashau ${ }^{1}$ Leomile Mangoedi ${ }^{1}$

\section{Affiliations:}

${ }^{1}$ Department of Christian Spirituality, Church History and Missiology, University of South Africa, South Africa

\section{Correspondence to:}

Thinandavha Mashau

Email:

mashatd@unisa.ac.za

Postal address:

PO Box 392, University of South Africa, Pretoria 0003,

South Africa

Dates:

Received: 18 June 2015

Accepted: 01 Aug. 2015

Published: 25 Nov. 2015

How to cite this article: Mashau, T.D. \& Mangoedi, L. 2015, 'Faith communities, social exclusion,

homelessness and disability: Transforming the margins in the City of Tshwane', HTS Teologiese Studies/ Theological Studies 71(3), Art. \#3088, 9 pages. http:// dx.doi.org/10.4102/hts. v71i3.3088

\section{Copyright:}

(C) 2015. The Authors.

Licensee: AOSIS

OpenJournals. This work is licensed under the Creative Commons Attribution License.

\section{Read online:}

Scan this QR code with your smart phone or mobile device to read online.
Social exclusion is a reality in South Africa today. Its faces are diverse and varied; social exclusion can be defined in terms of social, economic, political and religious dimensions. This diversity also applies to the context of homelessness in the City of Tshwane. The research on which this article is based sought to explore the issue of social exclusion from a religious perspective; it looked closely at how social exclusion manifests from a religious perspective in the context of homelessness and disability in the City of Tshwane. The thrust of this article is captured in the following question: how do homeless people and persons with disability experience social exclusion from faith communities? What do they say about the role that faith communities should play in addressing their marginalisation? These questions were answered by doing Contextual Bible Study of Acts 3:1-10 with the homeless in the City of Tshwane, thereby allowing them space for their voices to be heard as to how the faith community should respond to their plight. It became clear in this research that faith communities should always act as transforming agents to those in the margins.

\section{Introduction}

The statue of Cecil John Rhodes has fallen at the University of Cape Town. After this incident, other statues were defaced and vandalised; statues of Louis Botha outside Parliament and Queen Victoria in Port Elizabeth are such examples. Finally, in the City of Tshwane, the statue of Paul Kruger at the Church Square was defaced. These actions have become very much part of the current social discourse in South Africa. The wave to dismantle all statues attached to the history of colonialism, apartheid and white supremacy; it is not just a battle for public space but one of identity and belonging. It brings to the surface one of the most contentious discourses in the history of South Africa - the societal dichotomy of social 'inclusion' and 'exclusion'. This article reflects on the issue of social exclusion within the context of homelessness in the City of Tshwane.

Whilst the discourse of social inclusion and exclusion has its historical roots in the colonial and apartheid past (cf. Maylam 1995), democratic South Africa is being ravaged by the results of social exclusion, a matter that keeps resurfacing in the public discourse. Examples that can be cited are many, but the current debate around statues and xenophobic attacks on foreign nationals is prominent. Social exclusion in South Africa is like a demon in the house which we are failing to get rid of. The urgency and scope of this problem is expressed by Coplan (2009) when he says:

That South African favourite, social exclusion, has recently raised its hydra heads above the invisibility of everyday interaction again, not just its monstrous manifestations but also in its imaginaries, agendas, and representations. (p. 64)

Manifestations of social exclusion in different forms today are just symptoms of a much deeper division in our society. Speaking of democratic South Africa, Zulu (2013:143) agrees that it is one of the most unequal societies in the world. In their article, May and Meth (2007) explain how the unholy alliance of unemployment, poverty, and inequality continues to ravage our democratic society. The gap between the centre as represented by the rich and the margins as represented by the homeless in the City of Tshwane is widening. This situation has created a society which is divided and highly polarised. The continued division in our society is described by De Beer (2013) as follows:

Gender, class, power and racial constructs have caused deep fragmentation, not only psychologically but also physically. There are those running the laboratories and the asylums, and those who are the perpetual patients - objects of scrutiny and dissection. Our scrutiny of each other further dismembers. It represents a violation of dignity of the other. (p. 4)

Social exclusion has become a kind of a trademark of our society and urban spaces like the City of Tshwane bear marks of this reality. The 'different others' in our society continue to be 
marginalised in all sectors of life. The homeless in the City of Tshwane, a focus group in the larger project on homelessness, is one such example.

Whilst issues of social exclusion are well recorded on the social, economic and political front, it is a basic premise of this research that it is also a religious matter. And contrary to the generally accepted view that religious communities, by their nature, are embracing and integrating, they have also become places of social exclusion to the different others. The narrative of the lame man begging in Acts 3:1-10 is one such example in the Bible. It appears from the literature that faith communities today seem to be very exclusive and inaccessible. They have created religious codes that keep the 'different others' in the margins. This phenomenon of social exclusion is even more entrenched in churches when it comes to persons with disability, as in the case of Acts 3:1-10 (cf. Reynolds 2012).

It is clear from the foregoing that faith communities, as represented by the Christian church in our research, are not immune to the problem of social exclusion; hence, the need to reflect on the current situation of social exclusion as experienced by the homeless in Tshwane. Questions that arose were: how do the homeless and persons with disability experience social exclusion from faith communities? What do they say about the role that faith communities should play in addressing their marginalisation? In order to get answers to these questions and seek God's peace for the homeless in the City of Tshwane, this research allowed the socially excluded homeless in the city to be heard as they interpreted Acts 3:1-10 within the ambit of their own experiences. Seeing that Acts 3:1-10 deals with the issue of a lame man begging at the temple gate, the issue of disability featured prominently in the research on which this article is based. The article is structured as follows:

- literature review on faith communities, social exclusion, homelessness and disability in the context of Tshwane to map out the background to this research

- research methodology used

- theological reflection of Acts 3:1-10 to map out how trained readers of the text deal with issues under discussion; encounterological reading of Acts 3:1-10 to give space for voices of ordinary readers to emerge

- synthesis: emerging voices of ordinary readers are recorded in comparison to the voices of trained readers

- the conclusion.

\section{Literature review on social exclusion Social exclusion defined}

The concept 'social exclusion' was first used within the French context during the 1970s (cf. Davies 2005:4) and has since gained global recognition. It has become a kind of cliché to cover almost every kind of social ill (Beall 2002:43). The exercise to define 'social exclusion' is therefore very complex. There is no single definition of this phenomenon that captures the reality in every context. Grant, Blue and Harpham (2000:201) asserted that [s]ocial exclusion tends to be rooted in multiple forms of deprivation, related to issues such as employment status, housing, rights, education, gender or race, and is thus comprehensive in nature. (p. 201)

However, in this article, social exclusion is defined in terms of different dimensions that seek to define it, and the following can be mentioned.

\section{The social dimension of social exclusion}

The social dimension refers to exclusion from decision making, social services and community and family support (Adato, Carter \& May 2006:229).

\section{The economic dimension of social exclusion}

The economic dimension refers to exclusion from the opportunities to earn income, the labour market and access to assets (Adato et al. 2006:229).

\section{Political dimension of social exclusion}

Social exclusion is a political phenomenon, as Grant et al. (2000) declare: 'It is generally accepted that social exclusion goes beyond economic and social aspects of poverty to embrace political aspects such as political rights and citizenship'. The social, economic and political dimensions of social exclusion are interwoven and in some instances overlap.

\section{Social exclusion as a religious phenomenon}

Few scholars have reflected on this matter, especially in the City of Tshwane where there is a serious lack of literature in this field. Swart (2008) focused on the issue of social exclusion from a religious perspective, De Beer (2012) and Mashau (2014) added the issue of homelessness and land to the discourse. Whilst all three make a call for a church's involvement in a transformative way, they do not explicitly pay special attention to the issue of homeless persons with disability and their exclusion by the church; a matter which this article addresses in the light of Acts 3:1-10, a passage that deals with the crippled beggar at the temple gate called Beautiful.

\section{Social exclusion in the City of Tshwane}

Social exclusion is a global phenomenon; it is also very much alive in South Africa. With particular reference to the urban South Africa, De Beer (2008:185) concluded that '[l]ocal urban spaces become mirrors of what happens globally in arenas of greater connectedness for some and the increased exclusion of others'. It is not easy to define this concept, as emphasised by Du Toit (2008:139): 'In South Africa, the reception of "social exclusion" discourse has been complex'. The discourse around this phenomenon has also gained momentum to the point of becoming a cliché that defines every social ill in our context. It has its historical roots in the colonial and apartheid past of South Africa; however, since 
1994 it has received increasing attention from researchers, commentators and politicians who all agree that the gap between the rich and the poor in this country is widening by day.

Social 'inclusion' and 'exclusion' in South Africa, especially as it manifests in a city like Tshwane, has led to a total fragmentation of society. The enormity of this division is captured by De Beer (2013) as follows:

The city is dismembered - inner-city neighbourhoods, suburbs, townships and informal settlements, often deeply segregated, the one becoming a no-go area of the other, in opposition to each other and perpetual strangers of each other. The landless and homeless, the refugees and asylum-seekers find the city as a whole to be hostile territory, a place of banishment. (p. 4)

The faces of social exclusion in South Africa are diverse and varied. They range from the marginalisation of drug addicts, sex workers, and the homeless, to legal and illegal immigrants from other parts of Africa and the rest of the world. The focus of this article is, however, on the exclusion of the homeless, a matter which is receiving serious attention in the City of Tshwane. Various publications on this matter exist (e.g. Mashau \& Kritzinger 2014), but the research on which this article is based sought to explore it from a religious perspective by allowing the excluded homeless to express their views as to how they perceive the involvement of faith communities in response to their plight.

\section{Social exclusion and faith communities in Tshwane}

Of all things, religious communities should be models of 'accessible communities', a point of entry into God's love radiating through the lives of its participants (Reynolds 2012:33). Critical reflection on the faith communities, as represented by the Christian church in this article, has shown that churches have not always been places of inclusion. Churches in South Africa have shown different faces in their response to social exclusion and marginalisation of the poor; in this case, the homeless. Pieterse's (2011:3) view is that ' $[e]$ very faith community has its own view of how to be involved in society and in the social needs of individuals and communities'.

In exploring some of the responses of the church, De Beer (2012) highlights nine characteristics of the church:

- The absent church. This is captured as follows:

The church is strangely absent from many of these emerging or decaying realities - if not physically, then in terms of concrete engagement, and sadly, often by design instead of being a participating, inquisitive, learning and transformational companion. (De Beer 2012:253)

- The silent church. This kind of a church 'often fails to provide prophetic and proactive leadership' (De Beer 2012:254).

- The distant church. This church becomes only an observer to the realities of social exclusion (De Beer 2012:255).
- The church in competition. In this case the church competes with the homeless for space.

- The church as an accomplice in the state's effort to silence the poor. Speaking of the contestation between the Moreleta Park Dutch Reformed Church, the City of Tshwane residents of Woodhill Golf Estate and business, De Beer (2012) comments as follows:

On both sides of this contest for space are people professing to be Christians. The largest church in the city is separated from Woodlane Village's 3,500 residents by a simple fence. What is the gospel in such a fragmented urban context, in the contest for land and space? And how does it inform our understanding and practice of theological education? (p. 253)

- The divided church. There is a lack of partnership amongst churches and even other faith communities in tackling issues of homelessness and other social issues. De Beer (2013) comments on the disunity in the church and the divided approach to the above-mentioned matters as follows:

The church is a dismembered body - functioning for years in the same neighbourhood without speaking to each other, without eating at the same table whilst confessing to membership of one family. The church is failing to work in coordinated ways although we are supposedly one body, seriously dismembered and disfigured, impotent from generating life and growth in dying neighbourhoods. (p. 4)

- The transforming church. This is the engaging church, one that stands in solidarity with the homeless and other groups of marginalisation in the urban spaces like the City of Tshwane (cf. De Beer 2012:255). The responses of many churches to the social ills in our society have perpetuated the marginalisation of those who are socially excluded, such as the homeless and persons with disability in the City of Tshwane. In this case their presence in the city is unwelcome, as noted by De Beer (2013):

When our presence is so overwhelming that it overshadows the weaker voices of the poor, vulnerable girls, illegal asylum-seekers or informal street traders, it is a presence that should preferably have been kept at bay as it accentuates our strangeness, it becomes a 'heavy' presence, an unwanted presence. (p. 3)

The foregoing literature review laid the foundation in terms of understanding social exclusion, homelessness and disability. The following section focuses on the research methodology used in this study in order to unearth the voices of those in the margins.

\section{Research methodology}

In the research on which this article is based, the Bible as the main source helped us to develop a dialogue between the trained and the ordinary reader. The Bible was used as a hermeneutical key to unlock how ordinary readers interpret the Bible in their context of social exclusion and homelessness. It became clear that ordinary readers use different hermeneutical lenses to look at and analyse any given text; and in this case the historical context and grammatical analysis of the text itself were ignored and 
even compromised. As a result, the text was read from the perspective of our current context wherein the temple is viewed to have the same meaning as the church today. Whilst it is imperative that trained readers do proper exegesis of the text, their reading of it through the eyes of ordinary readers and their context help them (trained readers) to dispel the traditional approach of 'ivory tower' preoccupations (cf. eds. Mashau \& Kritzinger 2014:10).

The method that was used in conducting the research was Gerald West's Contextual Bible Study (cf. West 1993). The core of this approach is to read the Bible with the ordinary readers (West 1993:72). The reading and reflection of Acts 3:1-10 was done by a group of the homeless in the City of Tshwane, with the trained readers serving as facilitators as prescribed by the method.

The group of the homeless interviewed was comprised of persons between 17 and 54 years of age. The majority of the group were women who were housed in the Potter's House. Most men who attended the Bible study were not sheltered; they came from the streets.

The Bible study conducted by the researchers was comprised of 12 questions. The first and the second were answered by the whole group. From question three the group was then divided into four subgroups. At the end of each discussion they chose one person to represent the group. This approach proved to be a very successful tool in gathering data from participants. According to Greeff (2011:360), focus groups are 'a means of better understanding how people feel or think about an issue, product or service'.

To avoid unethical behaviour on our part as researchers (cf. Struwig \& Stead 2001:67), all participants (informants) were informed of the nature of this research and their consent was sought so that this work would be published in the form of a scholarly article. All informants were willing participants in the whole process of data gathering and the synthesis thereof.

\section{Theological reflection of Acts 3:1-10}

By scrutinising Acts 3:1-10 this section deals with theological reflection by learned readers of the biblical text on issues of faith communities, social exclusion, homelessness and persons with disability. An exegetical reading of Acts 3:110 points to the healing of a lame man outside the temple. The chosen text forms part of the bigger context and this is captured by Newman and Nida (1972) as follows:

This discourse (3.1-4.22) consists of three major parts: (1) 3.1-10 is the story of healing of the lame man; (2) 3.11-26 is the message of Peter to the people in the temple; and (3) 4.1-22 is the account of Peter and John before the Council, including not only the arrest and accusations but also the defence of Peter and the final outcome of the decision of the Council. (p. 67)

The research on which this article is based dealt with the first section of the discourse because this section provides a comprehensive picture that speaks to issues of the religious dimension of social exclusion, homelessness and persons with disability. The issue of homelessness is derived from within the broader scope of research on homelessness in the City of Tshwane and it finds resonance in this text as we reflect on the aspect of 'home' and 'family' as reflected in the case of the man who was born lame. If the lame man (Ac 3:1-10) experienced religious exclusion, that also had an economic dimension, and it is the case even more so for those people who are experiencing the social, economic, political and religious exclusion of being homeless. A further question arises about the extent of the exclusion of those who are homeless and at the same time have the same status of being persons with a disability.

In terms of the theological reflection of Acts 3:1-10, a number of pertinent issues are dealt with in the subsections that follow.

\section{Church and context}

Faith communities function within a particular context and have to respond to issues of social exclusion in that community. The healing of the lame man is taking place at the gate of the Temple in Jerusalem called Beautiful, one of the gates leading to the temple - the house of worship. The city of Jerusalem, the Temple of God in Jerusalem and the households of worshippers in this temple form part of this context.

\section{Church and agency}

The following characters are identified:

- the lame man from birth

- the household of the man who was lame from birth

- worshippers at the temple in Jerusalem

- leaders in the temple and in this case Peter and John are mentioned

- Jesus and his healing powers.

All these agents play a particular role in as far as issues of social exclusion, homelessness, and disability are concerned. In his comments about the Jewish tradition of charity, Speckman (1997:310) touched on the issue of agency as follows: '[H]e [Luke] consistently portrays a Jesus who (directly or through the apostles) responds to a beggar by transforming his/her condition'. It is clear that God is able to use human beings as agents of transformation, and that defines the calling of the communities of faith in the hour of exclusion and marginalisation.

\section{Church, disability and social exclusion}

Acts 3:1-10 demonstrates how social exclusion is even more entrenched in churches when it comes to persons with disability. Speaking in a different context, but on how persons with disability are received by faith communities, Reynolds (2012) says:

Disability unsettles easy assurances. It exemplifies how people can be represented in terms that exclude. Disability often comes to signify the way that some people are recognized as lacking 
something basic to what is understood as human, being abnormal, a body gone wrong. The implications of such 'recognition' which is more adequately a mis-recognition - extend far beyond disability, and in fact touch on the cultural, social, and religious systems by which human beings gain orientation in the world and traffic with each other. (p. 33)

In reading Acts 3:1-10, it is clear, without a doubt, that worshippers in the temple in Jerusalem were either ignorant or insensitive to the lame man's spiritual need to belong, to be part of their community and to be able to call their church his home. His longing to belong could only be satisfied when he was healed. After being healed, the man entered the temple walking, jumping and worshipping (Ac 3:8).

\section{The economics of church, disability and social exclusion}

Worshippers who donated money to the crippled beggar would not have appeased their consciences by just giving him some alms. There were two fundamental theological underpinnings that informed their actions: Jewish religious activities encouraged the giving of alms and therefore they were fulfilling their religious obligations or duties (Speckman 1997:310) and Jewish laws of purity. They would have considered anyone living with disability as considerably unclean and not worthy to enter the house of prayer and worship.

Economically, the lame man seems to have found a profitable occupation in his begging activities. It was economically viable for him; hence he was carried to the temple gate every day. It is clear that he was dependent on his disability to survive.

\section{Homelessness, disability and religious exclusion}

The man's disability excluded him from entering the temple. Because of his disability, those carrying him to the temple gate and worshippers were content when the man did not bother to join them for prayer and worship. His disability was taken as an excuse for him to stay away from religious participation. It is clear from the foregoing that the narrative of Acts 3:1-10 speaks of religious inclusivity and exclusivity; this exercise was perpetual. Worshippers went into the temple to offer their prayers and sacrifices, but the lame man was left begging at the Beautiful gate. It shows that this man was not at home in the church. Worshippers at the temple did not consider him to be part of their home or family, hence they did not take the trouble to carry him inside.

\section{Religious inclusivity and healing}

The narrative provides a missiological thrust for the whole discourse when recording the healing of the lame man. Firstly, the healing of the lame man presented Peter with the opportunity to share the gospel of and about Christ in the temple. Hamm (1986) remarks as follows:

Like the sights and sounds of the Pentecost miracle story of Acts 2, the cure of the man born lame becomes the subject of an interpretive speech by Peter to the people $(3,12-26)$ and of yet another speech to the leaders (4,8-12). (p. 21)
Hamm (1986) continues to point out how the whole narrative ignited the spirit of solidarity in prayer amongst believers:

Finally, the prayer of the community in Acts 4, 24-30 is triggered by the response of the Jerusalem officials to the healing, and the content of the prayer is a petition for God's continued support through gifts of 'signs and wonders' which in this context are healing and bold preaching, the very things already illustrated concretely in the healing and the speech of Acts 3. (pp. 305-306)

Religious inclusivity in addressing the needs of those who are socially marginalised opens the door for the preaching of the gospel - to share the healing and restorative power of Jesus Christ of Nazareth as Peter did.

Secondly, the man was given the opportunity to embrace his restoration which was holistically placed - on one hand his physical disability was healed and on the other hand it was the day of his salvation (cf. Hamm 1986:306). He was able to stand up, walk, jump and praise God. He was now liberated not only to be able to provide for himself physically (liberated from dependency) but also to be able to enter the house of God and join fellow family members in praising God. Speckman (1997:332) points out that 'an alternative to begging is offered, namely a total transformation of the person from being handicapped to being able'. Lastly, the community that excluded him because of his disability stood in awe and also praised God (Ac 3:10); and others came to see wonders of God (Ac 3:11). His healing had a great symbolic significance, namely of God welcoming his child home, amongst the brothers and sisters in God's family; this happened despite the social exclusion the lame man suffered earlier.

\section{Contextual reading of Acts 3:1-10}

In reading, interpreting and applying Acts 3:1-10 in the context of homelessness and social exclusion in the City of Tshwane, ordinary readers of the text concluded as follows.

On the question of what the text is all about, the entire group agreed that it was about Peter healing the crippled beggar. Although the ordinary readers of the text lacked any theological background or training, there was no doubt about their knowledge and understanding of the text. There was a general understanding of the text. They were able to engage it and through group discussions were able to understand what the text was all about. In addition to the general view that the text was about Peter healing the crippled beggar, ordinary readers immediately applied the text in their context of social exclusion and homelessness. In doing that they were able to retell the story in their own words and in light of their context. Group 3 concluded that 'the story is about God showing his power through Peter, because he used Peter to heal him'.

The group continued to say:

'[T] he story is about a crippled man who only wanted money, he was not a believer and he did not think that he can walk but he believed that by begging people going into the church. But 
because God knew what he needed he healed him by using Peter, so that he can be able to work for himself instead of depending on other people. And as Peter was about to pray for him he told him that he does not have silver and gold but he gave him something which is valuable, which is healing. And through the healing of the man people saw that there is healing people saw that there is power in the name of Jesus.' (Respondents of Group 3)

Whilst Group 2 reiterated what the latter group had said, they included that:

'[T] the story shows us that, when you go to the right place to look for help you will find God and also go to God expecting he will meet you at your needs.' (Respondents of Group 2)

Group 3 added that the man was crippled from birth and his 'only opportunity was to be a beggar and receive alms'.

\section{Faith communities and agency}

Following the opening discussion was a question about the main characters and what they knew about each one of them. This question speaks to the issue of agency and how every character was involved in matters of faith and social exclusion and/or faith and social inclusion as reflected in the healing of the lame man. Respondents identified six characters, namely Peter, John, the lame man, worshippers at the temple, God and Jesus:

- Peter: Peter was identified as the 'one who helped the crippled man to stand up. He was one of the disciples of Jesus'. Seeing that Peter prayed for the crippled beggar as opposed to giving him alms, someone in the group assumed that 'Peter didn't have money, [because] he was broke'. However, the act of Peter towards the beggar was welcomed as one of the respondents commented that he (Peter) 'gave the man what he really needed'.

- John: The group realised that Peter was not alone in healing the crippled beggar; he was in the company of John whom the group identified as 'Peter's accomplice, Peter's prayer partner and friend in Christ'. The respondents unanimously commended Peter and John for the act of healing. When asked who Peter and John represent in their context, Group 3 responded by saying that they represent the pastors of the churches who pray for the sick people.

- The lame man: The man who was referred to by the respondents as 'the crippled man' was healed. One of the respondents in the group also identified the man as someone who is 'dependent on others. He didn't know what was best for him hence he asked for money and lastly, he was carried to the temple'. The crippled beggar was not seriously disabled. When the ordinary readers engaged the text they did not feel sympathetic towards the lame man. They felt that the man was not debilitated but had a disability and therefore was able to help himself out of the situation. This section will be explained later in the article when issues of self-development are discussed.

- Worshippers at the temple: The ordinary readers identified the worshippers at the temple as people who financially supported the attitude (of dependency) of the crippled beggar. The healing of the crippled beggar appeared to be an amazing narrative to the ordinary readers of the text; but the respondents identified it as amazing also to the group of worshippers at the temple. When he (the crippled beggar) was healed, the group of worshippers at the temple were amazed.

- God: As much as Peter and John were identified as key people in the healing of the crippled man, the ordinary group took cognisance of God's intervention in the healing of the crippled man. One thing that stood out from the discussion was their assertion that God is more interested in our spiritual growth than in our (physical) needs. Some of the responses that came out of the group were that 'when God wants to deliver you, He works through people' and that 'the purpose of the man being crippled [was that] God wanted to reveal His power through Peter and John to be acknowledged'.

- Jesus: It was the calling of the name of Jesus that brought healing to the crippled beggar. The entire group agreed that there is power in the name of Jesus and that Jesus' name is the channel through which the power of God operates. They added that if you believe in him (Jesus), all is possible.

\section{Faith communities, disability and social exclusion}

The main point of this article is that faith communities have a vital role to play in the context of social exclusion, disability and homelessness. Ordinary readers were given a set of questions with the aim of eliciting the church's response to the issue of social exclusion, a matter which was also relevant to their context of homelessness in the City of Tshwane. Five questions were posed. The first question was: what picture does this story paint about the church? One of the respondents in Group 1 answered this question by saying that 'it shows that the church followers were not true believers, even after the crippled man did his testimony to them; they were amazed and running after Peter and John'. Group 2 in their answer also made a negative observation about the church. They answered by saying that:

'The church has the cruel people, because the man was sitting at the gate and no one offered to take him inside the church to pray for him, where as they were passing him at the gate every time.' (Respondents of Group 2)

One of the respondents in this group exclaimed that 'the church did not care about him because he was lame'.

The second question was: what is it that the church could have done better before the intervention of John and Peter? One of the respondents in Group 1 responded by saying that the 'church should have provided help by putting a man inside the church and pray with him to get well. They should have encouraged the man to have faith in God'.

The third question that was posed was: what is the response of the church in your context towards the lame today? One of the respondents in Group 2 said that: 
'They just want to take money from the lame. The church has become so materialistic that they disregard what they are called for - that is being shepherds to the lost flock. The church is competing with the lame for those hand-outs. It's just a dog eat dog [in the] world out there.' (Respondent, Group 2)

One of the respondents in Group 3 added:

'They feel pity for them. They think that the lame people must live on hand-outs from people and they cannot help themselves. The churches must have the Spirit of God and treat people as normal people and they must pray for them to be healed. They must teach them to be responsible and empower them to be independent.' (Respondent, Group 3)

The ordinary readers had nothing positive to say about the church. This should serve as a lesson to the church in terms of trying to understand its image in society and in mapping out how it participates in social activities aimed at transforming people. The church should, without doubt, take seriously its calling of serving as a transforming agent of the missio Dei (mission of God).

The fourth question was: what are the things that you think the church should do which they are currently not doing? The whole group responded by saying that the church should be encouraged to collect the tithes and take the money to the poor and widows; the lame should be taught skills because most of them are gifted - they should be helped to go to school; the church can be the centre of help for people in the community, a place to relieve people's burdens.

Not only did the ordinary readers mention the role that the church should play, they also included the government as a role player. According to them, the government should play a role in empowering them spiritually and with skills. The government is not aware that both men and women are suffering. Another concern, voiced by one of the respondents, was that:

'A woman has more options for survival: they can either get a rich boyfriend or [become a] prostitute. They can be taken in by anyone or go to brothels. Guys have limited options: crime or get a job.' (Respondent, Group 2)

There was consensus amongst the group that more attention should be given to the plight of men. Individuals made the group aware that there were shelters for males in the city but they were not operating well. Also, these shelters had initiated programmes to empower men however not all of the men participated in them. The significance of education was subsequently raised.

The fifth question was: what is it that the church could avoid in working with those in the margins? One of the respondents in Group 1 answered by saying that the church 'should avoid corruption and stop to give away money to people like they better give things like clothes, food parcels and create agents to seek work for the lame'. One of the respondents in Group 2 continued by saying that 'they [the lame] must not be used as an advertising fodder'. Another respondent in Group 3 added that 'they must stop telling them that they are sorry for them and they must stop treating them as outcast. They must not judge them'. One of the respondents in Group 4 concluded that

'[the church] should avoid creating dependency syndrome where will always depend on the hand-outs. The church should avoid discriminating among those who are lame regardless of whether they are South African citizens or not.' (Respondent, Group 4)

The conversation ended with the group having to identify the lame in their context. Group 2 identified them as:

'(a) people begging on the streets; (b) people who do not know Jesus as their saviour; (c) the unemployed; (d) any person who is in a situation that he cannot help him or herself.' (Respondents of Group 2)

When listening to the conversation of the ordinary readers of the text, it became very clear that they were observant as to how the church or faith communities respond to the issues raised.

\section{Disability, dependency and self-development}

It is apparent that when the ordinary readers engaged with the text, they were able to differentiate between being disabled and living with disability. According to them, the disability of the crippled beggar was not a reason for him to sit at the gate and beg. It became clear that cultivating a dependency mentality never crossed the minds of ordinary readers of the text as one of the solutions to the issue of social exclusion and the role that the church can play. When asked what is it that the lame man could have done differently to help himself, Groups 2 and 3 said that 'he should have asked people to take him inside the church to be prayed for instead of waiting at the gate and begging for money'. Group 4 put it in context when they answered by saying, 'He did this by asking for money. In our modern days he could have applied for disability grant. He could have identified his other Godgiven talents; maybe singing'. These comments raise issues of self-development and self-reliance as opposed to self-pity and dependency. These are critical issues that can contribute positively in resolving the problem of social exclusion and homelessness.

\section{Synthesis: Emerging voices}

In this article, the views of the trained readers of Acts 3:110 were used as a sounding board to enable the views of ordinary readers of the same text to emerge. According to West (1995:209), this step is not only critical in the contextual bible study method of reading and interpreting the Bible, it also allows space for critical interfacing space between the trained and ordinary reader of the same text. This process does not only benefit the ordinary reader, but the trained reader as well; so the relationship between the two types of readers is reciprocal. It also allows the trained reader space to read the Bible using the spectacles of the ordinary reader. West (1993) argues that: 
When we choose to read the Bible from the perspective of the poor and oppressed in the South African context we choose to hear the concerns of the vulnerable and marginalized and God's concern for them. (p. 14)

This ignites the spirit of humility in the trained reader who ordinarily would be hesitant to listen to such voices; and without doubt it allows space for a mission and missiology from below.

When a synthesis of voices of trained and ordinary readers was made, in the context of Acts 3:1-10, it became clear that ordinary readers of the text understood what the text was about. Whilst the trained readers would have provided a more theological thrust with regard to the historical placement of Acts 3:1-10 and its scope, ordinary readers did not care much about such a context and scope; they cared much about retelling the story in the language they best understand and also applying it within their own context of homelessness in the City of Tshwane. They saw this text for what it is; a spiritual guide and liberatory tool to provide lasting solutions to the problem of social exclusion and the role that faith communities, as represented by the church in this research, can and should play.

As for the main thrust of the narrative in Acts 3:1-10, trained readers and ordinary readers have four things in common, namely:

- the text is about the healing of the lame man

- God uses human agency to attend to human needs

- social exclusion is a reality and it is something that is practised by faith communities as well; especially when it comes to persons with disability

- faith communities should respond, as part of their calling, to the injustices of social exclusion and discrimination against the homeless and persons with disability.

The emerging voices of the ordinary readers can be summarised as follows:

- Social exclusion is a reality in the context of homelessness in the City of Tshwane; this exclusion is not only a reality in the areas of economics and politics, but also in the church.

- The faces of social exclusion in the context of homelessness in the City of Tshwane are diverse and varied. It became clear that persons with disability, those who are begging in the streets and the unemployed are part of the equation.

- To the homeless and persons with disability religious exclusion is a matter of serious concern in South Africa. With regard to persons with disability, Matsebula (2011) argues as follows:

Like all other churches in the world, many SA churches have not openly acknowledged their role in addressing disability. The church has not accepted that disability is a human right that requires mainstreaming in all respects. (p. 414)

- Religious exclusion is influenced by certain stereotypes that people in faith communities like the church hold against the homeless and persons with disability. This might also be caused by negligence on the side of the church (cf. Kritzinger, Meiring \& Saayman 1994:74).

- Faith communities should change their understanding and attitude towards the homeless and persons with disability. Persons with disability are not disabled and therefore should not serve as objects of the church's charity, for instance.

- Churches should become a home for everybody, including those who are socially marginalised, the homeless and persons with disability included. The lame man in Acts 3:1-10 should have been welcomed home, in God's family or household (temple), long before he received the healing. This would have sent a positive message that the church is a home for all irrespective of one's social status. More and more churches in the city should spill onto a sidewalk, as the Central Methodist Church in Johannesburg has done (Kuljian 2013).

- The church should serve as an agent of transformation, seeking to provide relief where it is needed but also empowering those in the margins to move to the mainstream of society.

- Faith communities should serve as healing agencies, having an impact on lives and transforming them through prayer and other rituals like the sacraments in their worship services.

- Faith communities should not work in isolation in attending to the needs of those in the margins; they should collaborate with government and other stakeholders.

\section{Conclusion}

Recent public discourse around statues and xenophobic attacks on foreign nationals are just manifestations of a deeper societal problem - social exclusion. Faces of social exclusion are diverse and varied; they include social, economic, political and religious dimensions. The first three are interwoven and well documented by researchers, but religious exclusion requires special attention, especially in the context of the homeless and persons with disability in the City of Tshwane.

The encounterological reading of Acts 3:1-10 by both trained and ordinary readers of the text, which led to a synthesis of their understanding and interpretation, unmasked the reality of social exclusion perpetuated by faith communities in the City of Tshwane; a reality which is experienced by the homeless and persons with disability as faces of those in the margins. Whilst those in the margins had negative views about faith communities and how they are responding to their challenges of social exclusion, homelessness and disability, it became clear that they remain optimistic that the church can still turn the tide and attend to their issues in transforming ways - serving as agents of transformation. Their presence, therefore, is not one that overwhelms and overshadows the margins, but one that transforms the margins and integrates them in the mainstream of social, economic, political and religious wellbeing of all. 


\section{Acknowledgements Competing interests}

The authors declare that they have no financial or personal relationships which may have inappropriately influenced them in writing this article.

\section{Authors' contributions}

M.T.D. (University of South Africa) was responsible for the following sections of the article: Introduction, Literature review on social exclusion, Theological reflection of Acts 3:1-10, Synthesis and Conclusion. M.L. (University of South Africa) was responsible for the following sections of the article: Abstract, Research methodology, Contextual reading of Acts 3:1-10, Synthesis, Conclusion in the article.

\section{References}

Adato, M., Carter, M.R. \& May, J., 2006, 'Exploring poverty traps and social exclusion in South Africa using qualitative and quantitative data', Journal of Development Studies 42(2), 226-247. http://dx.doi.org/10.1080/00220380500405345

Beall, J., 2002, 'Globalization and social exclusion in cities: Framing the debate with lessons from Africa and Asia', Environment \& Urbanization 14(1), 41-51. http:// dx.doi.org/10.1177/095624780201400104

Coplan, D.B., 2009, 'Innocent violence: Social exclusion, identity, and the press in an African democracy', Critical Arts: South-North Cultural and Media Studies 23(1), 64-83. http://dx.doi.org/10.1080/02560040902738982

Davies, J.S., 2005, 'The social exclusion debate: Strategies, controversies and dilemmas', Policy Studies 26(1), 3-27. http://dx.doi.org/10.1080/01442870500041561

De Beer, S., 2008, 'Contesting inner-city space: Global trends, local exclusion/s and an alternative Christian spatial praxis', Missionalia 36(2/3), 181-207.

De Beer, S., 2012, 'Urban South Africa: An opportunity for liberating theological education', Missionalia 40(3), 251-277. http://dx.doi.org/10.7832/40-3-32

De Beer, S.F., 2013, 'Absence, presence, remembrance: A theological essay on frailty, the university and the city', Verbum et Ecclesia 34(1), Art. \#855, 9 pages. http:// dx.doi.org/10.4102/ve.v34i1.855

Du Toit, A., 2008, 'Living on the margins: The social dynamics of economic marginalisation', Development Southern Africa 25(2), 139. http://dx.doi. org/10.1080/03768350802090493
Grant, E., Blue, I. \& Harpham, T., 2000, 'Social exclusion: A review and assessment of its relevance to developing countries', Journal of Developing Societies 16(2), 201-221. http://dx.doi.org/10.1163/156852200512058

Greeff, M., 2011, 'Information collection: Interviewing', in A.S. de Vos, H. Strydom, C.B. Fouché \& C.S.L. Delport (eds.), Research at grass roots: For the social sciences and human service professions, pp. 341-374, Van Schaik Publishers, Pretoria.

Hamm, D., 1986, 'Acts 3, 1-10: The healing of the temple beggar as Lucan theology', Biblica 67(3), 305-319.

Kritzinger, J.J., Meiring, P.G.J. \& Saayman, W.A., 1994, On being witnesses, Orion, Johannesburg.

Kuljian, C., 2013, Sanctuary: How an inner-city church spilled onto a sidewalk, Jacana Media, Auckland Park.

Mashau, T.D., 2014, 'More than just a piece of land: Power dynamics in the land discourse within the City of Tshwane', Missionalia 42(3), 192-211. http://dx doi. org/10.7832/42-3-64

Mashau, T.D. \& Kritzinger, J.N.J. (eds.), 2014, Pavement encounters for justice: Doing transformative missiology with homeless people in the City of Tshwane, AcadSA, Parow.

Matsebula, J.S.P., 2011, 'Persons with disability in South Africa', in S. Kabue, E. Mombo, J. Galgalo \& C.B. Peter (eds.), Disability, society, and theology: Voices from Africa, pp. 41-426, Zapf Chancery, Limuru.

May, J. \& Meth, C., 2007, 'Dualism or underdevelopment in South Africa: What does a quantitative assessment of poverty, inequality and employment reveal?', Development Southern Africa 24(2), 271-287. http://dx.doi. org/10.1080/03768350701327178

Maylam, P., 1995, 'Explaining the apartheid city: 20 years of South African urban historiography', Journal of Southern African Studies 21(1), 19-38. http://dx.doi. org/10.1080/03057079508708431

Newman, B.M. \& Nida, E.A., 1972, A translator's handbook on the Acts of the Apostles, American Bible Society, New York.

Pieterse, H.J.C., 2011, 'A church with character and its social capital for projects amongst the poor', HTS Teologiese Studies/Theological Studies 67(3), Art. \#1046, 8 pages. http://dx.doi.org/10.4102/hts.v67i3.1046

Reynolds, T.E., 2012, 'Theology and disability: Changing the conversation', Journal of Religion, Disability \& Health 16(1), 33-48. http://dx.doi.org/10.1080/15228967 .2012 .645612

Speckman, M.T., 1997, 'Beggars and gospel in Luke-Acts: Preliminary observations on an emerging model in the light of recent development theories', Neotestamentica 31(2), 309-337.

Struwig, F.W. \& Stead, G.B., 2001, Planning, designing and reporting research, Maskew Miller Longman, Cape Town.

Swart, I., 2008, 'Meeting the challenge of poverty and exclusion: The emerging field of development research in South African Practical Theology', International Journal of Practical Theology 12(1), 104-149. http://dx.doi.org/10.1515/IJPT.2008.6

West, G.O., 1993, Contextual Bible study, Cluster Publications, Pietermaritzburg.

West, G., 1995, Biblical hermeneutics of liberation: Modes of reading the Bible in the South African context, Cluster Publications, Pietermaritzburg.

Zulu, P., 2013, A nation in crisis: An appeal for morality, Tafelberg, Pietermaritzburg. 